\title{
Women as Key Agents in Sustainable Entrepreneurship: A Gender Multigroup Analysis of the SEO-Performance Relationship
}

\author{
Ana Criado-Gomis ${ }^{1}$, Maria-Angeles Iniesta-Bonillo ${ }^{2, *(\mathbb{D}}$, Amparo Cervera-Taulet $^{3}(\mathbb{D}$ and \\ Domingo Ribeiro-Soriano ${ }^{4}$ \\ 1 Department of Business Management, University of Castilla-La Mancha, 16071 Cuenca, Spain; \\ ana.criado@uclm.es \\ 2 Department of Economics and Business, University of Almería, 04120 Almería, Spain \\ 3 Department of Marketing, University of Valencia, 46022 Valencia, Spain; amparo.cervera@uv.es \\ 4 IUDESCOOP and Department of Business Administration, University of Valencia, 46022 Valencia, Spain; \\ domingo.ribeiro@uv.es \\ * Correspondence: miniesta@ual.es; Tel.: +34-950-214-008
}

Received: 2 January 2020; Accepted: 6 February 2020; Published: 9 February 2020

\begin{abstract}
Literature points out that the effect of sustainable entrepreneurship on firm performance may be contingent on internal factors, such as top manager characteristics. This paper proposes that the gender of a firm's chief executive officer (CEO) greatly influences the sustainable entrepreneurial orientation (SEO)-firm performance relationship. An empirical study was conducted on a stratified random sampling, collecting 210 questionnaires from top managers of firms in Valencia (Spain). A multigroup moderation analysis method was used. The results confirm that women tend to increase the positive effect of SEO in firm performance.
\end{abstract}

Keywords: gender analysis; sustainable entrepreneurial orientation; firm performance; sustainable entrepreneurship

\section{Introduction}

The challenge of creating a habitable planet for all people and at all levels-economic, social, and environmental-remains as one of the main problems facing world leaders today. This is demonstrated by the continuous efforts to promote the scope of sustainable development, such as the United Nations 2030 Agenda with its 17 Sustainable Development Goals, the celebration of global climate summits, and the commitment to new business models based on social economy or circular economy, among other actions. A long time has passed since the term sustainable development was officially recognized for the first time in 1987 in the Brundtland Report, embodying the concept that present needs are met without compromising the ability of future generations to meet their own needs [1]. More than 30 years later, though it may seem that we have not succeeded in reaching said equilibrium, efforts to achieve this objective have not been abandoned.

In this sense, companies play a key role in contributing to a more equitable and lasting development [2-4]. Sustainable entrepreneurship emerges in the literature as a solution to this problem, understanding that both areas of knowledge-entrepreneurship and sustainability—are not mutually exclusive [5], but instead are allies [6] in achieving a balance between economic performance, social equity, and environmental resilience [7].

The development of this area of study requires going beyond purely conceptual approaches and exploring new approaches at an empirical level. In this sense, the study of business strategic orientations is seen as a new research opportunity to make progress towards achieving the sustainable 
development of companies [8]. Specifically, the configuration of strategic orientation towards sustainable entrepreneurship is insufficiently studied in the literature, as well as its relationship with other business variables $[9,10]$. The present study seeks to shed some light in this regard by studying the relationship between the strategic orientation to sustainable entrepreneurship and business outcomes, and the effect of internal moderating variables that may affect this relationship.

Some research suggests that behind this promotion of sustainability there are women entrepreneurs who, from positions of leadership, influence business strategy [11-14]. However, there are still too few contributions to validate the impact that gender can have on the development of a sustainable venture. This work aims to contribute in this line by studying for the first time the contingent relationship between the gender of the manager and the orientation towards sustainable entrepreneurship and business performance.

For the purposes of this study, a literature review is conducted. Initially, this review highlights the relationship between the orientation towards sustainable entrepreneurship and business performance, as well as the role of the firm manager in that relationship. Subsequently, an analysis of women's relationship with sustainable entrepreneurship is carried out, which includes the formulation of several hypotheses. The present paper continues by developing testing methods and finishes by discussing the empirical findings and presenting a number of conclusions and future research lines.

\section{Materials and Methods}

\subsection{Sustainable Entrepreneurial Orientation (SEO) Effect on Business Performance}

Historically, researchers have addressed the difficult task of understanding the complex and changing adaptive processes that organizations face in their respective environments [15]. In these contexts, which tend to be uncertain and hostile, companies must respond with the adoption of strategic orientations [16]. The literature generated in relation to this concept not only demonstrates the complexity of its study, but also the efforts made to identify the effects of different strategic orientations on various business outcomes [16].

Some authors identify these orientations based on the models that guide companies' interactions with the environment, how they improve communication, and their understanding of the environment (customers, competitors, internal operations, etc.) in order to ultimately achieve a competitive advantage. In this regard, over the past two decades, researchers made numerous attempts to elucidate the effects of strategic orientation on business performance (e.g., [17]).

Among the strategic orientations that make it possible to improve business performance, sustainable entrepreneurial orientation (SEO) is proposed in the literature as the combination of entrepreneurial and sustainability strategic orientations. Previous works by Criado-Gomis et al. $[9,10]$ extensively developed the nature and conceptualization of the SEO construct from both theoretical [9] and empirical [10] approaches, following in the footsteps of other authors in the study of sustainable entrepreneurship (e.g., [6]). They conceived sustainable entrepreneurial orientation (SEO) under the multiple strategic orientation approach $[16,18]$, whose main purpose is attaining the best business opportunities through an adequate combination of resources and capabilities in a firm. Thus, according to the dynamic capabilities perspective, as an extension of the resource-based view, SEO is seen as a dynamic capability that fosters opportunity exploration and exploitation through the combination of other capabilities, such as entrepreneurial orientation (EO) and sustainability orientation (SO).

On the one hand, EO is a well-developed construct in academic literature. Its consolidation in marketing, strategic management, and entrepreneurship areas in recent decades gave rise to two leading, and distinct, research postures: (1) Miller's [19] and Covin and Slevin's [20] proposals of EO as an aggregated concept of innovativeness, risk-taking, and proactiveness where these components or subdimensions are correlated and covary in the same direction; and (2) Lumpkin and Dess's [21] conceptualization of EO as a multidimensional concept of innovativeness, risk-taking, proactiveness, competitive aggressiveness, and autonomy as independent dimensions which do not need to covary 
and usually behave differently. As is customary in the literature, the present study follows the first approach mentioned.

On the other hand, $\mathrm{SO}$ is a recent and scarcely studied strategic orientation. Defined at a firm-level (as occurs with EO), SO integrates organizational interests towards sustainability from a holistic approach that involves environmental, social, and economic concerns. This perspective facilitates a strategic corporate governance for a win-win setting, which takes into account stakeholders as participants and not only as a medium for an enterprise's own interest. A company can be involved in $\mathrm{SO}$ at different levels (i.e., opportunity, compliance, and/or cost), each of which represents a distinct phase of corporate sustainability [22].

Thus, SEO is understood as a general strategic orientation of the organization that shows a predisposition for proactiveness, innovativeness, and risk-taking behaviors on the path to sustainable development $[9,23]$.

Regarding the relationship of SEO with business performance, the literature is still scarce at this point [10]; although most studies do establish the existence of a relationship between performance and EO and SO when independently addressed [24]. Even if this relationship tends to be positive in most studies, some authors advocate this approach from a multiple strategic orientation perspective [25].

Based on the results provided in the literature, the authors propose the following hypothesis:

\section{Hypothesis H1. SEO is positively related to firm performance.}

\subsection{Manager's Function in SEO}

Strategic orientations are collected in the literature as chief executive officers' (CEOs) cognitive models [26], the views of top management teams [27], or the orientation of the manager [27]. This is because the manager plays an essential role in the company's adaptation to the environment. Thus, the manager, the strategic orientation of the company, and superior performance are interrelated concepts, although the role of the manager has somewhat blurred in recent times [17].

In this line, the individual role of the manager in the relationship between SEO and performance is not addressed in the literature. Frishammar and Andersson [17] noted that the emphasis on strategic directions has overshadowed the importance of the individual entrepreneur's role in business success, particularly in small businesses. Sustainable entrepreneurship is usually only defined at the individual level when it comes to environmental entrepreneurship [28], dealing more with environmental entrepreneurs or eco-entrepreneurs than environmentally entrepreneurial organizations [29,30]. However, from a holistic point of view, sustainable entrepreneurship incorporates not only the sustainable entrepreneur, but also the sustainable context and sustainable enterprise [31]. In this respect, within the framework of entrepreneurship theory, SEO is a strategic orientation that responds to the role that companies, as private economic agents and social institutions, play in environmental and social challenges [8].

Delving deeper into the role of the individual in entrepreneurship and sustainability separately, the conclusions are often similar. On the one hand, entrepreneurship has been approached at the micro level from the point of view of the individual entrepreneur (e.g., [32]). However, in the case of EO, although it is initially described at the individual level [33] (e.g., [19]), it soon becomes fully conceived at the firm level (e.g., [20,34-36]). Thus, the focus of research on entrepreneurship shifted from the individual entrepreneur to the entrepreneurial activity of the company [19]. However, subsequent studies have highlighted the importance of the individual, focusing on the relationship of some characteristics of managers with EO and business performance [36,37]. Yang and Wang [38] analyzed age, gender, educational background, and functional experience as top management team characteristics. Richard et al. [39] addressed race and gender, while Wales et al. [36] studied CEO narcissism, and Richard et al. [40] analyzed CEO industry tenure and CEO position tenure, all in relation to $\mathrm{EO}$.

On the other hand, with regard to sustainability, different theories highlight the decisive role of management in the inclusion of sustainability at the strategic business level (e.g., agency theory, 
top management theory, or stakeholder theory [41,42]). Indeed, authors such as Banerjee et al. [43] indicated that manager interest can moderate a company's commitment to sustainability. In the case of $\mathrm{SO}$, unlike most strategic orientations, it is usually defined in the literature at the individual level [44], taking into account the importance of the commitment of managers to sustainable development, so it may be integrated into the organization (e.g., $[3,8,22,23,45]$ ); that is, describing the individual belief system directed towards the principles of sustainability [46,47].

Thus, although in this research SEO as a strategic orientation is conceived at the company level and, consequently, so are EO and SO, the importance of the manager in strategic orientation [27], sustainable entrepreneurship [29,43], and business performance $[40,46]$ is evident. For this reason, the authors propose to study the relationship between these variables from a gender perspective.

\subsection{Women's Role in Promoting Sustainable Entrepreneurship}

The current situation of unsustainability shows that environmental, social, and economic systems are not functioning [48]. Undoubtedly, organizations' approach to sustainability requires a great deal of effort not only in adjusting the standards that have so far prevailed in terms of business regulation around the world, but also in their response to stakeholders, whose interests are often at odds at the social, environmental, and economic levels [48]. This difficulty led to some criticism of corporate proactivity that was perceived as insufficient and too rhetorical in the adoption of environmental and social responsibility practices [49]. According to some authors, achieving sustainable development requires a radical change in education, learning, and business practice; so that entrepreneurial enterprises become part of the solution and contribute to sustainability [48].

However, creating sustainability is not the same as reducing unsustainability [50]. A business model that is not economically sustainable will go bankrupt, leaving room for other types of alternative models; if, on the contrary, it is not environmentally sustainable, it will cease to be valid because it threatens life on the planet; and, if it is not socially sustainable, it will lose legitimacy and be rejected by society. Therefore, the three bases of sustainability are necessary in the long term for the business model to be competitively sustainable [51]. To this end, the motivations underlying the adoption of integrated sustainability may be productive, which could also be true for commercial competitiveness, legitimacy, and ecological responsibility [52], according to the contributions of Bansal and Roth [53] and González-Benito and González-Benito [54].

In fact, authors such as Mendis [55] proposed this holistic perspective in which economic business decisions are equally environmental and social decisions, since the opposite would be an ethically indefensible position [56] obsessed with continued growth [48]. In this regard, the manager is seen as a driver of sustainable development and, to a greater extent, is a woman, as women demonstrate a greater social and environmental commitment [11,12]. Kearins and Schaefer [48] argued that, although the relationship between women and sustainability is a common research topic, it is not so much so when it comes to entrepreneurship. In this regard, they noted that this relationship between sustainable entrepreneurship and women deserves more attention in the literature. From the point of view of sustainability, several studies indicate that women contribute positively to the achievement of true sustainable development (e.g., [11,57-60]), based, among others, on the theory of gender socialization, which states that women have stronger ethics of care [58], or on proposals such as ecofeminism [57].

Ecofeminism is directly related to the guiding principles of the so-called ecocentric approach, also called the new ecological paradigm [61] or ecocentric responsibility paradigm [62]. It focuses its efforts on the global ecosystem as well as the equilibrium of all its elements and species (i.e., on the conservation of the environment for its intrinsic value [63] in order to achieve sustainability). Both approaches understand that women are the drivers towards reaching sustainable development, and emphasize community and cooperative structures, intuition and consensus, rather than hierarchy $[48,63]$. They also arise in opposition to the anthropocentric approach, also called the dominant environmental paradigm in the West [63], which places human needs and desires before the needs and survival of 
other species. According to some authors, this was driven by the Brundtland Report [1] (e.g., [63,64]), which they suggest is responsible for the failure to achieve true sustainable development $[63,65]$.

Thus, confronted with this traditional, Western neoclassical economic perspective that underlies most interpretations of sustainable development and prevents the authentic achievement of social and environmental objectives, some authors proposed new perspectives to overcome the barriers imposed by neoclassical economics to ensure the principle of fair subsistence, both for the natural environment and for each individual and society as a whole [56]. The concept of sustainable sufficiency takes up these postulates from ecofeminist, ecocentric, or Buddhist perspectives, among others, focusing on unsustainable consumption patterns [66] within a society obsessed with maximizing short-term economic growth while ignoring the limits imposed by the finite nature of natural resources [67]. In this sense, the framework for sustainable sufficiency is related to the dematerialization of the economy; that is, with the reduction of the use of materials in production and consumption, creating products and services that, with a considerably lower environmental impact, provide consumers with the same level of performance and, at the same time, contribute to social welfare [56].

In this sense, the literature considers women as drivers of change through leadership based on the principles of sustainable sufficiency: well-being and social values, environmental concern, empathy and justice [11,12,58]. Johnsson-Latham [60] argued that women have a lower environmental impact and live more sustainably than men, making gender equality a precedent for sustainable development.

From the point of view of entrepreneurship, the contributions of researchers who study women entrepreneurship are also increasing. As Baycan-Levent et al. [68] argued, there has been an evolution in the study of women entrepreneurship, from a partial focus on some differences between men and women entrepreneurs, to an integrated approach based on liberal feminist and social feminist theories. Liberal feminist theory explains the differences between men and women by focusing on systemic and discriminatory factors. Feminist social theory focuses on the process of socialization to understand these differences.

Although studies indicate that gender differences in entrepreneurship imply that, among other issues, women-led enterprises are often smaller, less performing, and need-motivated [68-71], there are aspects of women-led enterprises that promote sustainable development [18]. The fact that they are mostly companies in the service sector [68] may imply the development of products and services in accordance with the product-service system [72], which is integrated into the sustainable sufficiency approach [56]. In addition, since women's motivation in entrepreneurship is often directed towards achievement, valuing social and qualitative aspects over economic ones, working with local networks, and pursuing a balance between non-economic and economic objectives $[68,73]$, their entrepreneurial traits can be seen as an engine for achieving sustainability, rather than as gender obstacles [48,68-71].

Therefore, although there are hardly any studies on the role of women in sustainable entrepreneurship, recent studies such as Outsios and Farooqi [12] show that women have an entrepreneurial tendency to contribute to global sustainability, and their inclusion in management teams ensures that they are moving in this direction [11]. Men's more aggressive and resource-wasting entrepreneurial vision may result in greater ventures and increased income, but it is also more likely to result in unsustainable entrepreneurial behavior [38]. However, this does not mean that women-led enterprises do not perform well [48], but that they are balanced in economic and non-economic terms [68].

The present review of the literature indicates that a relationship between the orientation towards sustainable entrepreneurship, women managers, and business performance, which is the subject of this research, may therefore exist. This relationship has not been measured as such, thus, we develop our proposal based on the approximations in the EO study on its relationship with business performance, which is the one most widely studied by authors.

In this sense, the literature proposes some contingent models with internal and external variables to explore the relationships of EO with business performance [74], focusing on one variable and exploring the dependence of these on given factors; in this case, the variables that act as moderators, such as CEO 
industry tenure, CEO position tenure, or middle-manager charisma in terms of leadership [37]. Most of the models proposed are therefore moderate-effect models in which the EO-performance ratio varies as a function of a specific variable $[75,76]$. Some studies focused on the analysis of the impact of gender on EO and sustainable entrepreneurship. Most researchers accept that entrepreneurial intentions are higher among men than women [77], with almost twice as many men entrepreneurs [78]. However, when it comes to small businesses, empirical results indicate that it is women who tend to show a higher EO [79,80]. The same is true when it comes to sustainable entrepreneurship, where the women surveyed are most likely to engage in such behavior [47].

Based on these results provided in the literature, the following hypothesis is put forward:

Hypothesis H2. The relationship between SEO and firm performance (PERF) is moderated by gender.

The hypotheses proposed are shown in Figure 1.

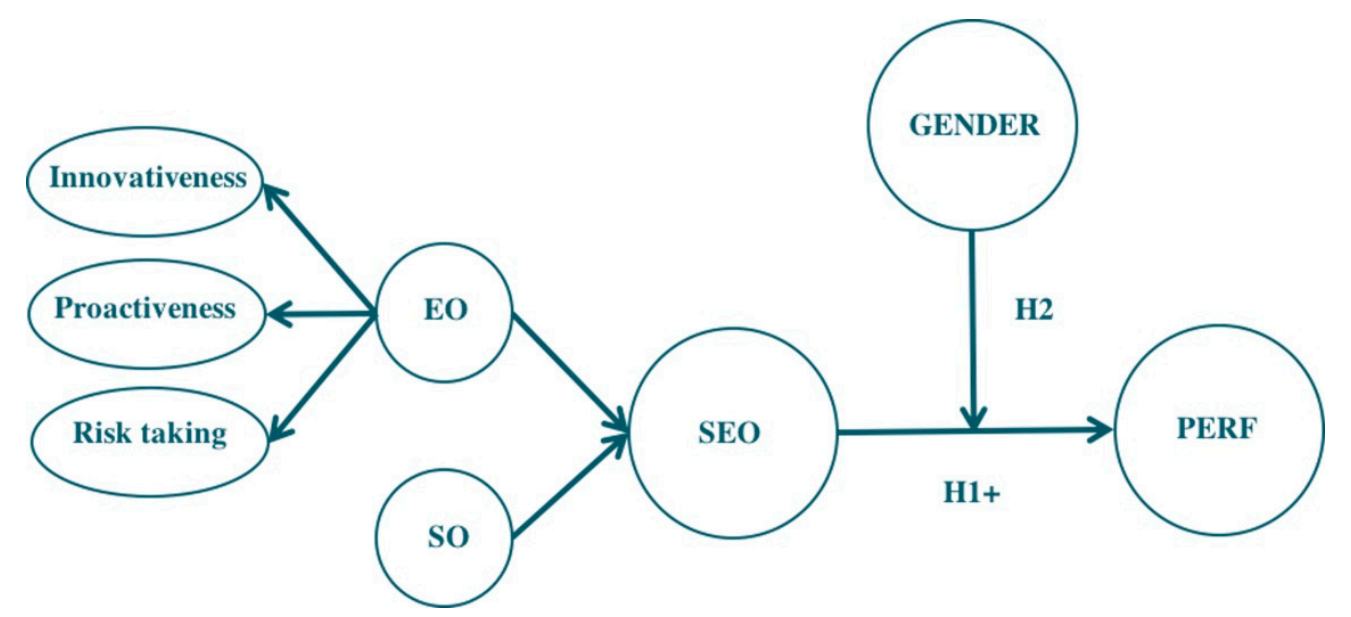

Figure 1. Contingent model proposed. Abbreviations: EO, entrepreneurial orientation; SO, sustainability orientation; SEO, sustainable entrepreneurial orientation; PERF, firm performance.

\subsection{Method}

\subsubsection{Sample Selection}

A personal questionnaire was administered to a sample of 210 multi-sector firm managers in Valencia, one of the three largest cities in Spain: 126 from the city of Valencia, and the rest from its metropolitan area. The sampling procedure was a stratified random sample, and sample units were selected in proportion to the size of each sector (i.e., industry, livestock and agriculture, construction and services) and given a reliability of $95.45 \%$ and $a+/-7 \%$ of error.

Table 1 contains the information about the characteristics of the firms in the sample: data related to the firm itself-location, productive sector, size, and age- and data related to the interviewed manager-gender, age, position, education, and professional experience. It indicates that the companies are run either by a woman $(49.5 \%)$ or a man $(50.5 \%)$. Overall, $71.0 \%$ belong to the service sector, while $15.2 \%$ correspond to industry, $11.9 \%$ are construction firms, and $1.9 \%$ belong to the agriculture and livestock sector. Further, $95.7 \%$ of the companies have fewer than 20 employees, and $72 \%$ are more than six years old. Managers are older than 35 years of age in $81.5 \%$ of the sample; $69.5 \%$ of the owners and managers have a basic-to-medium training level. All the features described are similar to those of the overall population studied. 
Table 1. Respondent characteristics.

\begin{tabular}{|c|c|c|}
\hline & No. of Firms & $\%$ \\
\hline \multicolumn{3}{|c|}{ (a) Firm Location } \\
\hline Valencia city & 126 & 60.0 \\
\hline Valencia metropolitan area & 84 & 40.0 \\
\hline \multicolumn{3}{|c|}{ (b) Firm Productive Sector } \\
\hline Agriculture and livestock & 4 & 1.9 \\
\hline Industry & 32 & 15.2 \\
\hline Construction & 25 & 11.9 \\
\hline Services & 149 & 71.0 \\
\hline \multicolumn{3}{|c|}{ (c) Firm Size (No. of Employees) } \\
\hline$<5$ & 164 & 78.1 \\
\hline $5-10$ & 29 & 13.8 \\
\hline $11-20$ & 8 & 3.8 \\
\hline $21-50$ & 6 & 2.9 \\
\hline $51-100$ & 2 & 1.0 \\
\hline$>100$ & 1 & 0.5 \\
\hline \multicolumn{3}{|c|}{ (d) Age } \\
\hline$<1$ year & 19 & 9.0 \\
\hline $1-2$ years & 15 & 7.1 \\
\hline $3-5$ years & 25 & 11.9 \\
\hline $6-10$ years & 27 & 12.9 \\
\hline $11-15$ years & 14 & 6.7 \\
\hline $16-20$ years & 23 & 11.0 \\
\hline $21-25$ years & 15 & 7.1 \\
\hline$>5$ years & 72 & 34.3 \\
\hline \multicolumn{3}{|c|}{ (e) Manager Gender } \\
\hline Women & 104 & 49.5 \\
\hline Men & 106 & 50.5 \\
\hline \multicolumn{3}{|c|}{ (f) Manager Age } \\
\hline$<25$ & 8 & 3.8 \\
\hline $25-34$ & 31 & 14.8 \\
\hline $35-44$ & 81 & 38.6 \\
\hline $45-54$ & 58 & 27.6 \\
\hline $55-65$ & 26 & 12.4 \\
\hline$>65$ & 6 & 2.9 \\
\hline \multicolumn{3}{|c|}{ (g) Manager Position } \\
\hline Entrepreneur/owner/partner & 140 & 66.7 \\
\hline CEO & 47 & 22.4 \\
\hline $\mathrm{CFO}$ & 13 & 6.2 \\
\hline R\&D manager & 5 & 2.4 \\
\hline Production manager & 5 & 2.4 \\
\hline \multicolumn{3}{|c|}{ (h) Education } \\
\hline No studies & 0 & 0.0 \\
\hline Basic/primary & 62 & 29.5 \\
\hline Secondary & 84 & 40.0 \\
\hline Undergraduate & 58 & 27.6 \\
\hline Master's degree & 6 & 2.9 \\
\hline $\mathrm{PhD}$ & 0 & 0.0 \\
\hline \multicolumn{3}{|c|}{ (i) Professional Experience } \\
\hline$<1$ year & 0 & 0.0 \\
\hline $1-2$ years & 5 & 2.4 \\
\hline $3-5$ years & 7 & 3.3 \\
\hline $6-10$ years & 28 & 13.3 \\
\hline $11-15$ years & 50 & 23.8 \\
\hline $16-20$ years & 32 & 15.2 \\
\hline $21-25$ years & 21 & 10.0 \\
\hline$>25$ years & 67 & 31.9 \\
\hline
\end{tabular}

Abbreviations: $\mathrm{CEO}$, chief executive officer; $\mathrm{CFO}$, chief financial officer; $\mathrm{R} \& \mathrm{D}$, research and development. 


\subsubsection{Measures}

To ensure context validity, we extracted measurement scales from previous studies and adapted them to our context and objectives. Five-point Likert-type scales were used for all constructs $(1=$ strongly disagree; 5 = totally agree).

To measure SEO, two scales were considered following the recommendation of Miles et al. [6]: one for sustainability orientation and one for entrepreneurial orientation [10]. The measurement of EO was carried out with a scale adapted from Matsuno et al. [18] which, in turn, was adapted from Miller [19] and other authors ([20,81,82]). This scale includes three dimensions: three risk-taking items, two proactiveness items, and two innovativeness items. The SO scale was adapted from that of Bos-Brouwers [22]. This scale reflects the sustainable innovative processes and focuses on the stages an organization successively adopts in order to be sustainable: the relevance of sustainability for the firm and its perception as a duty, a cost, and/or an opportunity.

To measure business performance, the scales of Santos-Vijande et al. [83] and García-Rodríguez et al. [84] were adapted to the context of this study. The scale includes four items for financial outputs: ROI (return on investment) and ROS (return on sales); profitability and achievement of financial objectives; and another four items for market outputs (market share, sales incomes, new customers, and sales growth). As suggested by Wiklund [85], all the items were compared with the main competitor over a period of one year.

\subsubsection{Statistical Method}

This work applies the system of structural equations based on variance (partial least squares), using the SmartPLS ${ }^{\circledR}$ computer statistical tool (v. 3.2.1) [86] to process the data collected with the questionnaire and to adhere to the planned objectives. Increasing attention to the validity of constructs in general and a more rigorous evaluation of the measurement properties of constructs has prompted procedures based on models of structural equations of latent variables to be considered in the literature as suppliers of tests of reliability, convergent validity, and discriminant validity on the construct. This approach is herein utilized as it is much more thorough [87] and highly widespread in the field of economics and business management [88], and in studies on OE and sustainability (e.g., [80,88]). Likewise, researchers consider that structural equations contribute to the integrated and systematic treatment of both theoretical concepts-hardly measurable and not directly observable-and the existing relationships between these constructs analyzed globally considering the possible measurement errors that are not always observed directly [89]. Regarding the choice of the type of analysis of structural equations, authors such as Lechner and Gudmundsson [80] stated that partial least squares (PLS) is particularly appropriate for constructs such as EO. In addition, according to Chin [90] and Lévy-Mangin and Varela-Mallou [91], the use of PLS is more appropriate when the researcher focuses on prediction and has a combination of formative and reflective indicators (as is the case of SEO) in the measurement of epistemic relationships between latent variables [92]. Consequently, modeling based on Structural Equations Program (EQS), Amos, or Lisrel was not contemplated.

Following Cadogan's [25] proposal, SEO, considered here as a multiple strategic orientation, is defined in this investigation as a formative construct comprised of the $\mathrm{EO}$ and $\mathrm{SO}$ subconstructs. In this sense, SEO is conceived as a third-order multidimensional construct with a reflective first-order, reflective second-order, and formative third-order [93].

\section{Results}

\subsection{Power test}

Before proceeding with the analysis of the model, the questions regarding the required sample should be considered. PLS follows a segmentation treatment of complex models that allows working with small sample sizes. Chin and Newsted [94] chose the power test for a more accurate assessment of the sample size requirement, ensuring with a minimum probability of $80 \%(1-\beta=1-0.20)$, that balance 
was achieved between the $\alpha$ error of 0.05 and the $\beta$ error of 0.20 [95]; that is to say, that the researcher will not accept the null hypothesis when it is false. In the present research, a test with the power calculation software $G^{*}$ Power $^{\circledR}$ 3.1.9.2. gives values superior to 0.80 , as recommended by Cohen [95], meaning that the $\mathrm{R}^{2}$ obtained in this PLS analysis would be significantly different from zero.

Once the minimum sample size is confirmed, the model is estimated, which, in PLS, is analyzed and interpreted in two stages. The first stage of valuation of the measurement model analyzes whether the theoretical concepts are correctly measured with the observed variables. Thus, reflective constructs are evaluated by validity (i.e., they actually measure what is intended to be measured) and reliability (i.e., they measure in a stable and consistent manner), and formative constructs based on external and nomological validity, multicollinearity potential, and weights of the manifest variables. On the other hand, the second stage consists of the assessment of the structural model, which evaluates the magnitude and significance of the relationships between the different variables.

\subsection{Measurement Model}

The proposed model presents a third-order multidimensional construct. It is composed of both reflective and formative indicators, which require a step-by-step approach [96]. Regarding the first-order variables of the measurement model, the reliability of the reflective items indicates that most have loadings greater than 0.7 [97]. Only two items have lower loadings (EORISK3 and SOR2) (Table 2). Nevertheless, both loadings are greater than 0.5 [98]. For $p<0.001$, all the items are significant and present a convergent validity greater than 0.5 [99]. Therefore, all items are maintained with the intention of not removing information that is useful to estimate the latent variable [100].

Table 2. Measurement model and reliability and validity measures.

\begin{tabular}{|c|c|c|c|c|c|}
\hline Construct/Dimension/Item & Loading & Weight & Composite Reliability & AVE & TOL/VIF \\
\hline \multicolumn{6}{|l|}{ SEO } \\
\hline Entrepreneurial Orientation & 0.679 & $0.791 * * *$ & 0.788 & 0.560 & $0.88 / 1.137$ \\
\hline Innovativeness & 0.565 & $0.316^{* * *}$ & 0.865 & 0.762 & \\
\hline EOINN1 & 0.844 & & & & \\
\hline EOINN2 & 0.901 & & & & \\
\hline Risk-taking & 0.798 & & 0.856 & 0.670 & \\
\hline EORISK3 & 0.643 & $0.134^{* * *}$ & & & \\
\hline EORISK4 & 0.857 & & & & \\
\hline EORISK5 & 0.929 & & & & \\
\hline Proactiveness & 0.850 & & 0.858 & 0.751 & \\
\hline EOPRO6 & 0.909 & & & & \\
\hline EOPRO7 & 0.822 & & & & \\
\hline Sustainability Orientation & 0.496 & $0.396 *$ & 0.910 & 0.719 & $0.88 / 1.137$ \\
\hline SOR1 & 0.894 & & & & \\
\hline SOR2 & 0.657 & $0.288^{* * *}$ & & & \\
\hline SOR3 & 0.916 & & & & \\
\hline SOR4 & 0.898 & & & & \\
\hline Business Performance & & & 0.969 & 0.796 & \\
\hline BPMK1 & 0.862 & & & & \\
\hline BPMK2 & 0.897 & & & & \\
\hline BPMK3 & 0.882 & & & & \\
\hline BPMK4 & 0.886 & & & & \\
\hline BPFIN5 & 0.878 & & & & \\
\hline BPFIN6 & 0.909 & & & & \\
\hline BPFIN7 & 0.906 & & & & \\
\hline BPFIN8 & 0.914 & & & & \\
\hline
\end{tabular}

${ }^{*} p<0.05 ;{ }^{* *} p<0.01 ;{ }^{* * *} p<0.001$ (t (4999), two-tailed test). Abbreviations: AVE, average variance extracted; TOL, tolerance; VIF, variance inflation factor. 
Composite reliability was above 0.8 in all cases [99] (see Table 2) and surpassed the limit indicated by Nunnally [101]. Average variance extracted (AVE), which assesses convergent validity, was greater than 0.5 [99]. The discriminant validity, evaluated by the Fornell-Larcker criterion, the heterotrait-monotrait ratio (HTMT), and the cross-loadings matrix, is confirmed for all constructs.

Regarding the evaluation of the measurement model for the second-order variable (EO), the loading for the innovativeness dimension was 0.565 , therefore, it is below the threshold of 0.707 [97]. Nevertheless, it was not eliminated because of its conceptual relevance, the weight above zero (0.316) [100] and the significance at a $99.9 \%$ confidence interval [98]. EO shows a composite reliability (CR) and an AVE greater than 0.7 and 0.5, respectively. Discriminant validity is confirmed following Fornell-Larcker's criterion, heterotrait-monotrait ratio (HTMT), and the cross-loadings matrix.

With regard to the third-order variable's measurement model (SEO), as it is a formative construct, it cannot be performed with a traditional evaluation [89]. Given the theoretical validity of the construct [92], we assessed the discriminant, nomological, and external validity of the construct, as well as the multicollinearity, the weights, and the indicator's significance (Table 2). In this case, both EO and SO are important for the construction of SEO as a formative variable, where EO is a greater contributor (see weight in Table 2).

\subsection{Structural Model}

To test hypothesis H2, concerning the moderating effect between SEO and firm performance, a product indicator approach is used, as it provides better results than other approaches [102]. In order to assess predictive relevance, we confirm that the $R^{2}$ value is 0.149 , slightly higher than 0.1 [103], and the $R^{2}$ value of the model without the moderating effect is 0.120 (Figure 2).

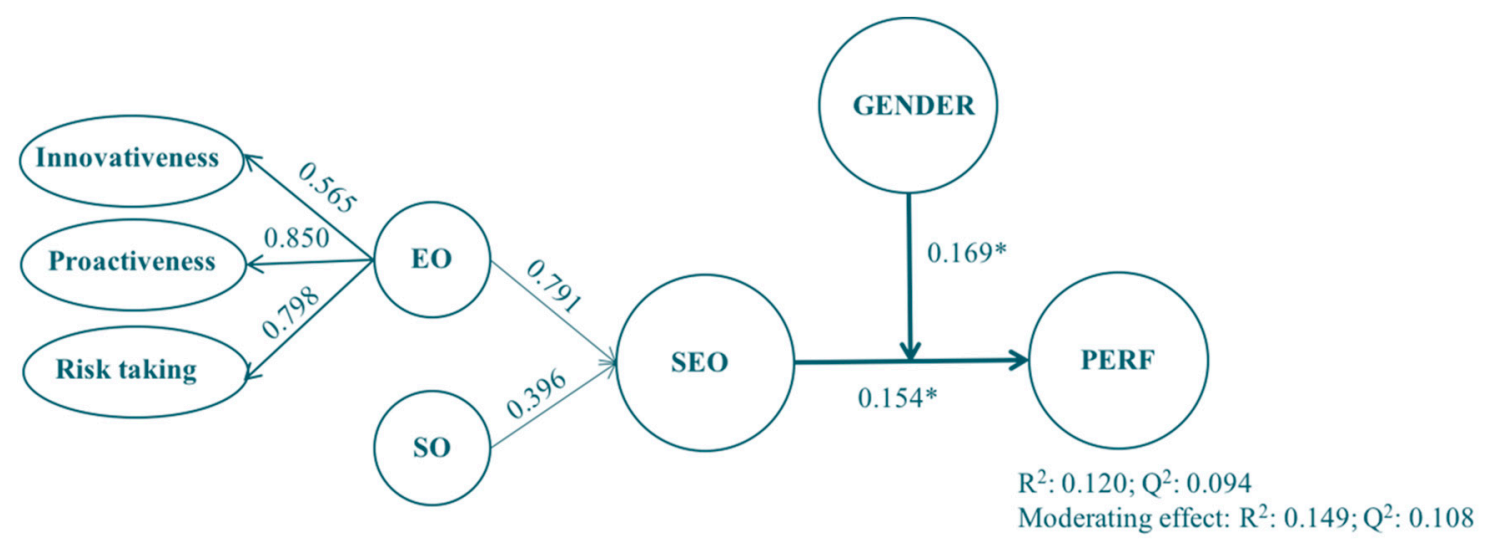

Figure 2. Structural model results. Note: ${ }^{*} p<0.05$ ( $\mathrm{t}(4999)$, two-tailed test). Abbreviations: EO, entrepreneurial orientation; $\mathrm{SO}$, sustainability orientation; $\mathrm{SEO}$, sustainable entrepreneurial orientation; PERF, firm performance.

A bootstrap procedure of 5000 subsamples was carried out (based on Student's t (4999), two-tailed test). Results show the significance of the moderating role of gender between SEO and firm performance at the $95 \%$ confidence interval $(t$-value $=2.578)$. Predictive relevance was measured with the Stone-Geisser test $\left(Q^{2}\right)$ by applying a blindfolding process. It was positive and slightly superior to 0.108 , the value obtained without the moderating effect, thus supporting Hypothesis 2.

Furthermore, the goodness-of-fit (GoF) test showed a value of 0.325 , between the acceptable values for $\mathrm{GoF}_{\text {medium }}(0.25)$ and $\mathrm{GoF}_{\text {large }}(0.36)$, according to the baseline values given by Wetzels et al. [104] for validating the PLS model globally. Additionally, in order to determine the predictive power of the model, the SRMR (standardized root mean square residual) composite factor model was 0.043 , below the limited 0.08 , thus confirming that the structural model is significant [105]. 


\subsection{Multi-Group Analysis}

In the present study, Hypothesis 2 represents moderating effects. As gender is a categorical variable, following other authors such as Afonso et al. [106], a multi-group comparison was herein carried out, as recommended by Henseler and Fassot [107]. This approach makes it possible to verify the moderating role of the manager's gender in the SEO-performance relationship [88]. Before performing the multi-group analysis, the stability of the invariance-configural, compositional, and equal mean values and invariances-was first checked and, consequently, confirmed [108].

Multi-group analysis involves the division of the sample according to the moderating variable. Group 1 is made up of men respondents (106 cases) and group 2 is made up of women respondents (104 cases). Each group is then estimated separately; and statistically significant differences in path coefficients are interpreted as moderating effects [109]. According to Sarstedt et al. [110], there are four approaches to analyzing these groups: the parametric approach, considered the most liberal; the permutation and confidence-based approaches, which are the most conservative; and, the strictest of all, the Henseler's multi-group approach. As for the latter, Henseler [111] proposed an extension that is even more developed called the PLS-MGA (MultiGroup Analysis) approach, which indicates significant differences between groups when these are below 0.05 or above 0.95 . In this paper, the multi-group analysis was carried out using the parametric and PLS-MGA approaches to compare the differences between the method considered the most liberal and the strictest among researchers.

Table 3 shows that in the multi-group analysis, moderation is confirmed both from the perspective of the parametric approach and from the strictest PLS-MGA approach. Therefore, the results confirm $\mathrm{H} 2$, indicating that the proposed moderating influence exists and is more intense for the women's group than for the men's group, meaning that a woman manager seems to increase the positive influence of SEO on business performance.

Table 3. Multi-group analysis.

\begin{tabular}{|c|c|c|c|c|c|c|c|}
\hline \multirow[b]{2}{*}{ Relationship } & \multicolumn{5}{|c|}{ Parametric Test } & \multicolumn{2}{|c|}{ PLS-MGA } \\
\hline & Path G1 & Path G2 & $\begin{array}{c}\text { Path } \\
\text { (G1-G2) }\end{array}$ & $\begin{array}{c}t \text {-Value } \\
\text { (G1 vs. G2) }\end{array}$ & $\begin{array}{c}p \text {-Value } \\
\text { (G1 vs. G2) }\end{array}$ & $\begin{array}{c}\text { Path } \\
\text { (G1-G2) }\end{array}$ & $\begin{array}{c}p \text {-Value } \\
\text { (G1 vs. G2) }\end{array}$ \\
\hline $\begin{array}{c}\mathrm{H} 2 \\
\mathrm{SEO} \rightarrow \mathrm{PERF}\end{array}$ & 0.033 & 0.352 & 0.318 & 2.054 * & 0.041 & 0.318 & 0.981 \\
\hline
\end{tabular}

\section{Discussion}

Our results are an important contribution to the study of the role of gender in sustainable entrepreneurship. On the one hand, the data obtained show that companies with an SEO have a positive performance and, on the other hand, that this relationship is higher in companies led by women. Therefore, the promotion of entrepreneurship among women towards a sustainability-oriented entrepreneurship can favor the success of their companies in financial and market terms; overcoming some gender barriers, highlighted by a number of authors, was related to lower performance when compared with men's companies (e.g., $[13,68])$. These data confirm the contributions of previous studies, which emphasize the role of women in achieving sustainable development (e.g., [11,14,57-60]).

Moreover, these results also provide an incentive for companies to focus on sustainable development, invalidating unsustainable arguments based on the alleged lack of profitability of these companies. As opposed to "compulsory" reasons, often understood in legal, ethical, reputational, and competitive terms, an entrepreneurial approach may foster the incentives for companies to address sustainability issues [2]. Thus, the opportunities that derive from sustainable entrepreneurship are important challenges for organizations today [5].

On the path to achieving "sustainability-as-flourishing" [112], companies should understand that a strategic orientation towards sustainable entrepreneurship has a positive impact on performance, 
providing an incentive to adopt it. Although some authors may believe this argument is based on a form of "weak sustainability" for using business performance as a bridge to sustainability [48], the adoption of sustainable behavior by companies and, therefore, their managers, is a gradual process [22].

Issues related to sustainable development are often technical and involve scientific uncertainty. In addition, translating pro-sustainability attitudes into actual behavior can be problematic for many companies [113]. Corporate sustainability is therefore complex and multifaceted, requiring the proposal of a broader framework for action than the triple bottom line proposed by Elkington [114]. It must incorporate a clear understanding of how stakeholders can be engaged in this process towards sustainable development [115] and achieve true integrated and holistic sustainability. In this regard, the resources and capabilities of women entrepreneurs are underutilized, undervalued, and invisible [48]. Their vision of commitment to the local environment [73] favors the start-up of sustainable entrepreneurial companies, as does the smaller size of their companies, which may also be a sign of a greater propensity to become sustainable entrepreneurs [116].

From a gender perspective, the promotion of entrepreneurship led by women, seen as an opportunity for companies to achieve sustainable development, can be framed within women's economic empowerment policies. Furthermore, it can be included among the efforts to achieve women's effective and equal participation in leadership in all areas, such as politics, society, and business. These efforts that are currently translated into government goals, such as the 5.5 gender-related goal of the United Nations Sustainable Development Goals [117] or the European Union's sustainability strategy [14], could prove beneficial if a predisposition in business for sustainable entrepreneurship led by women exists. Thus, as long as progress is made towards achieving real and effective equality of opportunity between women and men, the challenges for a sustainable world might come closer to being achieved. Researchers and institutions have before them the opportunity to develop a new line of contributions within gender and management studies, as recently occurred with advances in topics such as female entrepreneurship and technology, or female entrepreneurship and financing, for example.

Therefore, regarding future research, a wider approach to women's role in sustainable entrepreneurial orientation could be of interest, analyzing the stage of sustainability adopted, as well as other measures of performance related to environmental and social outputs. In this sense, longitudinal and cross-cultural analysis would also contribute to the development of this area of study, since the study presented here is limited to a specific moment in a specific region of Spain. Thus, the possibilities of development in future research are considerable.

Furthermore, the relative newness of the concept of SEO and the measurement of its relationship with different variables, such as manager's gender and firm performance, entail certain limitations when it comes to analysis. These limitations mainly derive from the selection of theoretical alternatives in the literature [24]; in this case, the EO scale. Although the measurement instrument was previously supported by other researchers, the composite reliability of the innovativeness dimension is close to the accepted limit. In this sense, a review of this measurement scale is recommended.

Author Contributions: A.C.-G., M.-A.I.-B., A.C.-T., and D.R.-S. have equally contributed to the work in this research. This paper is part of a research project directed by A.C.-T. All authors have read and agreed to the published version of the manuscript.

Funding: This research received funding by the university chair Catedra Ciudad de Valencia, an agreement signed by the InnDEA Foundation of the local government of Valencia and the University of Valencia.

Conflicts of Interest: The authors declare no conflicts of interest. The funders had no role in the design of the study; in the collection, analyses, or interpretation of data; in the writing of the manuscript, or in the decision to publish the results. 


\section{References}

1. World Commission on Environment and Development (WCED). Our Common Future; Oxford University Press: Oxford, UK, 1987; ISBN 019282080X.

2. York, J.G.; Venkataraman, S. The entrepreneur-environment nexus: Uncertainty, innovation, and allocation. J. Bus. Ventur. 2010, 25, 449-463. [CrossRef]

3. Millar, C.C.J.M.; Gitsham, M. The role of management development in achieving a culture change towards sustainability in the organization. J. Manag. Dev. 2013, 32. [CrossRef]

4. Varadarajan, R. Toward sustainability: Public policy, global social innovations for base-of-the-pyramid markets, and demarketing for a better world. J. Int. Mark. 2014, 22, 1-20. [CrossRef]

5. Gawel, A. Entrepreneurship and sustainability: Do they have anything in common? Poznán Univ. Econ. Rev. 2012, 12, 5-16.

6. Miles, M.P.; Munilla, L.S.; Darroch, J. Sustainable corporate entrepreneurship. Int. Entrep. Manag J. 2009, 5, 65-76. [CrossRef]

7. Hall, J.K.; Daneke, G.A.; Lenox, M.J. Sustainable development and entrepreneurship: Past contributions and future directions. J. Bus. Ventur. 2010, 25, 439-448. [CrossRef]

8. Kuckertz, A.; Wagner, M. The influence of sustainability orientation on entrepreneurial intentionsInvestigating the role of business experience. J. Bus. Ventur. 2010, 25, 524-539. [CrossRef]

9. Criado-Gomis, A.; Cervera-Taulet, A.; Iniesta-Bonillo, M.A. Sustainable Entrepreneurial Orientation: A Business Strategic Approach for Sustainable Development. Sustainability 2017, 9, 1667. [CrossRef]

10. Criado-Gomis, A.; Iniesta-Bonillo, M.Á.; Cervera-Taulet, A. Sustainable entrepreneurial orientation within an intrapreneurial context: Effects on business performance. Int. Entrep. Manag. J. 2018, 14, 295-308. [CrossRef]

11. Buil-Fábrega, M.; del Mar Alonso-Almeida, M.; Bagur-Femenías, L. Individual dynamic managerial capabilities: Influence over environmental and social commitment under a gender perspective. J. Clean. Prod. 2017, 151, 371-379. [CrossRef]

12. Outsios, G.; Farooqi, S.A. Gender in sustainable entrepreneurship: Evidence from the UK. Gend. Manag. Int. J. 2017, 32, 183-202. [CrossRef]

13. Kumar, A. Women entrepreneurs in a masculine society: Inclusive strategy for sustainable outcomes. Int. J. Organ. Anal. 2013, 21, 373-384. [CrossRef]

14. Grosser, K. Corporate social responsibility and gender equality: Women as stakeholders and the European Union sustainability strategy. Bus. Ethics Eur. Rev. 2009, 18, 290-307. [CrossRef]

15. Miles, R.E.; Snow, C.C.; Meyer, A.D.; Coleman, H.J., Jr. Organizational strategy, structure, and process. Acad. Manag. Rev. 1978, 3, 546-562. [CrossRef]

16. Noble, C.; Sinha, R.K.; Kumar, A. Market orientation and alternative strategic orientations: A longitudinal assessment of performance implications. J. Mark. 2002, 66, 25-39. [CrossRef]

17. Frishammar, J.; Andersson, S. The overestimated role of strategic orientations for international performance in smaller firms. J. Int. Entrep. 2009, 7, 57-77. [CrossRef]

18. Matsuno, K.; Mentzer, J.T.; Ozsomer, A. The effects of entrepreneurial proclivity and market orientation on business performance. J. Mark. 2002, 66, 18-32. [CrossRef]

19. Miller, D. The correlates of entrepreneurship in three types of firms. Manag. Sci 1983, 29. [CrossRef]

20. Covin, J.G.; Slevin, D.P. Strategic management of small firms in hostile and benign environments. Strateg. Manag. J. 1989, 10, 75-87. [CrossRef]

21. Lumpkin, G.T.; Dess, G.G. Clarifying the entrepreneurial orientation construct and linking it to performance. Acad. Manag. Rev. 1996, 21, 135-172. [CrossRef]

22. Bos-Brouwers, H.E.J. Corporate Sustainability and Innovation in SMEs: Evidence of Themes and Activities in Practice. Bus. Strategy Environ. 2010, 19, 417-435. [CrossRef]

23. Scridon, M.A.; Achim, S.A.; Pintea, M.O.; Gavriletea, M.D. Risk and perceived value: Antecedents of customer satisfaction and loyalty in a sustainable business model. Econ. Res. Ekon. Istraživanja 2019, 32, 909-924. [CrossRef]

24. Rauch, A.; Wiklund, J.; Lumpkin, G.T.; Frese, M. Entrepreneurial orientation and business performance: An assessment of past research and suggestions for the future. Entrep. Theory Pract. 2009, 33, 761-787. [CrossRef]

25. Cadogan, J. International marketing, strategic orientations and business success: Reflections on the path ahead. Int. Market. Rev. 2012, 29, 340-348. [CrossRef] 
26. Hitt, M.A.; Dacin, M.T.; Tyler, B.B.; Park, D. Understanding the differences in Korean and U.S. Executives' strategic orientations. Strateg. Manag. J. 1997, 18, 159-167. [CrossRef]

27. Dess, G.G.; Davis, P.S. Porter's (1980) generic strategies as determinants of strategic group membership and organizational performance. Acad. Manag. J. 1984, 27, 467-488. [CrossRef]

28. Hockerts, K.; Wüstenhagen, R. Greening Goliaths versus emerging Davids-Theorizing about the role of incumbents and new entrants in sustainable entrepreneurship. J. Bus. Ventur. 2010, 25, 481-492. [CrossRef]

29. Dean, T.J.; McMullen, J.S. Toward a theory of sustainable entrepreneurship: Reducing environmental degradation through entrepreneurial action. J. Bus. Ventur. 2007, 22, 50-76. [CrossRef]

30. Gibbs, D. Sustainability Entrepreneurs, Ecopreneurs and the Development of a Sustainable Economy. Greener Manag. Int. 2009, 55, 63-78. [CrossRef]

31. Spence, M.; Gherib, J.B.B.; Biwolé, V.O. Sustainable entrepreneurship: Is entrepreneurial will enough? A north-south comparison. J. Bus. Ethics 2011, 99, 335-367. [CrossRef]

32. Thompson, J.L. The facets of the entrepreneur: Identifying entrepreneurial potential. Manag. Decis. 2004, 42, 243-258. [CrossRef]

33. Covin, J.G.; Miller, D. International entrepreneurial orientation: Conceptual considerations, research themes, measurement issues, and future research directions. Entrep. Theory Pract. 2014, 38, 11-44. [CrossRef]

34. Lumpkin, G.T.; Brigham, K.H.; Moss, T.W. Long-term orientation: Implications for the entrepreneurial orientation and performance of family businesses. Entrep. Reg. Dev. 2010, 22, 241-264. [CrossRef]

35. Covin, J.G.; Lumpkin, G.T. Entrepreneurial orientation theory and research: Reflections on a needed construct. Entrep. Theory Pract. 2011, 35, 855-872. [CrossRef]

36. Wales, W.J.; Gupta, V.K.; Mousa, F.T. Empirical research on entrepreneurial orientation: An assessment and suggestions for future research. Int. Small Bus. J. 2013, 31, 357-383. [CrossRef]

37. Gao, Y.; Ge, B.; Lang, X.; Xu, X. Impacts of Proactive Orientation and Entrepreneurial Strategy on Entrepreneurial Performance: An Empirical Research. Technol. Forecast. Soc. Chang. 2018, 135, 178-187. [CrossRef]

38. Yang, L.; Wang, D. The impacts of top management team characteristics on entrepreneurial strategic orientation. Manag. Decis. 2014, 52, 378-409. [CrossRef]

39. Richard, O.C.; Barnett, T.; Dwyer, S.; Chadwick, K. Cultural diversity in management, firm performance and the moderating role of entrepreneurial orientation dimensions. Acad. Manag. J. 2004, 47, 255-268. [CrossRef]

40. Richard, O.C.; Wu, P.; Chadwick, K. The impact of entrepreneurial orientation on firm performance: The role of CEO position tenure and industry tenure. Int. J. Hum. Resour. Manag. 2009, 20, 1078-1095. [CrossRef]

41. Connelly, B.L.; Ketchen, D.J.J.; Slater, S.F. Toward a 'Theoretical toolbox' for sustainability research in marketing. J. Acad. Market. Sci. 2011, 39, 86-100. [CrossRef]

42. Cronin, J.J.; Smith, J.S.; Gleim, M.R.; Ramírez, E.; Dawn-Martínez, J. Green marketing strategies: An examination of stakeholders and the opportunities they present. J. Acad. Market. Sci. 2011, 39, 158-174. [CrossRef]

43. Banerjee, S.B.; Iller, E.S.; Kashyap, R.K. Corporate environmentalism: Antecedents and influence of industry type. J. Mark. 2003, 67, 106-122. [CrossRef]

44. Parboteeah, K.P.; Addae, H.M.; Cullen, J.B. Propensity to support sustainability initiatives: A cross-national model. J. Bus. Ethics 2012, 105, 408-413. [CrossRef]

45. Kraus, S.; Breier, M.; Dasí-Rodríguez, S. The art of crafting a systematic literature review in entrepreneurship research. Int. Entrep. Manag. J. 2020. [CrossRef]

46. Gagnon, M.A.; Michael, J.H.; Elser, N.; Gyory, C. Seeing green in several ways: The interplay of entrepreneurial, sustainable and market orientations on executive scanning and small business performance. J. Market. Dev. Compet. 2013, 7, 9-28.

47. Wagner, M.; Maximilians, J. Ventures for the public good and entrepreneurial intentions: An empirical analysis of sustainability orientation as a determining factor. J. Small Bus. Entrep. 2012, 25, 519-531. [CrossRef]

48. Kearins, K.; Schaefer, K. Women, entrepreneurship and sustainability. In The Routledge Companion to Global Female Entrepreneurship; Routledge: London, UK, 2017; pp. 64-77.

49. Banerjee, S.B. Who sustains whose development? Sustainable development and the reinvention of nature. Organ. Stud. 2003, 24, 143-180. [CrossRef]

50. Ehrenfeld, J.R. The roots of sustainability. MIT Sloan Manag. Rev. 2005, 46, 23-25. 
51. Aguado-Muñoz, R. La competitividad sostenible: Nuevo reto para las empresas y la sociedad. Bol. Estud. Econ. 2010, LXV, 263-281.

52. Murillo-Luna, J.L.; Garcés-Ayerbe, C.; Rivera-Torres, P. Estrategia medioambiental y expectativas de ventajas competitivas. Cuad. Estud. Empresariales 2008, 18, 9-31.

53. Bansal, P.; Roth, K. Why companies go green: A model of ecological responsiveness. Acad. Manag. J. 2000, 43, 717-736. [CrossRef]

54. González-Benito, J.; González-Benito, O. A study of the motivation for the environmental transformation of companies. Ind. Market. Manag. 2005, 34, 462-475. [CrossRef]

55. Mendis, P. Buddhist economics for human development. J. SID 1993, 2, 13-17.

56. Lamberton, G. Sustainable sufficiency-An internally consistent version of sustainability. Sustain. Dev. 2005, 13, 53-68. [CrossRef]

57. Hessing, M. Women and sustainability: Ecofeminist perspectives. Alternatives 1993, 19, 14-21.

58. Braun, P. Going Green: Women entrepreneurs and the environment. Int. J. Gend. Entrep. 2010, 2, $245-259$. [CrossRef]

59. Hunter, L.; Hatch, A.; Johnson, A. Cross-national gender variation in environmental behaviours. Soc. Sci. Quart. 2004, 85, 677-694. [CrossRef]

60. Johnsson-Latham, G. A study on gender equality as a prerequisite for sustainable development. In Report to the Environment Advisory Council; Ministry of the Environment: Stockholm, Sweden, 2007; pp. 1-90.

61. Dunlap, R.; Liere, K.V.; Mertig, A.; Jones, R.E. Measuring endorsement of the new ecological paradigm: A revised NEP scale. J. Soc. Issues 2000, 56, 425-442. [CrossRef]

62. Purser, R.E.; Park, C.; Montuori, A. Limits to anthropocentrism: Toward an ecocentric organization paradigm? Acad. Manag. Rev. 1995, 20, 1053-1089. [CrossRef]

63. Borland, H.; Lindgreen, A. Sustainability, Epistemology, Ecocentric Business, and Marketing Strategy: Ideology, Reality and Vision. J. Bus. Ethics 2013, 117, 173-187. [CrossRef]

64. Sharma, S.; Aragón-Correa, J.A.; Rueda, A. The contingent influence of organizational capabilities on proactive environmental strategy in the service sector: An analysis of North American and European ski resorts. Can. J. Adm. Sci. 2007, 24, 268-283. [CrossRef]

65. Hart, S.L.; Milstein, M.B. Global sustainability and the creative destruction of industries. Sloan Manag. Rev. 1999, 41, 23-33.

66. Dabbous, A.; Tarhini, A. Assessing the Impact of Knowledge and Perceived Economic Benefits on Sustainable Consumption through the Sharing Economy: A Sociotechnical Approach. Technol. Forecast. Soc. Chang. 2019, 149, 119775. [CrossRef]

67. Hahn, R. ISO 26000 and the standardization of strategic management processes for sustainability and corporate social responsibility. Bus. Strategy Environ. 2013, 22, 442-455. [CrossRef]

68. Baycan-Levent, T.; Masurel, E.; Nijkamp, P. Gender differences in ethnic entrepreneurship. Int. J. Entrep. Innov. Manag. 2006, 6, 173-190. [CrossRef]

69. Istenič, T.; Ograjenšek, I.; Sambt, J. The gender gap in economic dependency over the life cycle: Some theoretical and practical considerations. Econ. Res. Ekon. Istraživanja 2018, 31, 188-205. [CrossRef]

70. Kompa, K.; Witkowska, D. Factors affecting men's and women's earnings in Poland. Econ. Res. Ekon. Istraživanja 2018, 31, 252-269. [CrossRef]

71. Qu, D.; Guo, S.; Wang, L. Experience, tenure and gender wage difference: Evidence from China. Econ. Res. Ekon. Istraživanja 2019, 32, 1169-1184. [CrossRef]

72. Mont, O.K. Clarifying the concept of product-service system. J. Clean. Prod. 2002, 10, 237-245. [CrossRef]

73. Pallarés-Blanch, M.; Tulla, A.F.; Vera, A. Environmental capital and women's entrepreneurship: A sustainable local development approach. Carpath. J. Earth Environ. Sci 2015, 10, 133-146.

74. Dess, G.G.; Lumpkin, G.T.; Covin, J.G. Entrepreneurial strategy making and firm performance: Tests of contingency and configural models. Strateg. Manag. J. 1997, 18, 677-695. [CrossRef]

75. Fayolle, A.; Basso, O.; Bouchard, V. Three levels of culture and firms' entrepreneurial orientation: A research agenda. Entrep. Reg. Dev. 2010, 22, 707-730. [CrossRef]

76. Kreiser, P.M.; Davis, J. Entrepreneurial orientation and firm performance: The unique impact of innovativeness, proactiveness, and risk-taking. J. Small Bus. Entrep. 2010, 23.1, 39-51. [CrossRef]

77. Díaz-García, M.C.; Jiménez-Moreno, J. Entrepreneurial intention: The role of gender. Int. Entrep. Manag. J. 2010, 6, 261-283. [CrossRef] 
78. Shinnar, R.S.; Giacomin, O.; Janssen, F. Entrepreneurial perceptions and intentions: The role of gender and culture. Entrep. Theory Pract. 2012, 36, 465-493. [CrossRef]

79. Runyan, R.C.; Huddleston, P.; Swinney, J. Entrepreneurial orientation and social capital as small firm strategies: A study of gender differences from a resource-based view. Int. Entrep. Manag. J. 2006, 2, 455-477. [CrossRef]

80. Lechner, C.; Gudmundsson, S.V. Entreprenerial orientation, firm strategy and small firm performance. Int. Small Bus. J. 2014, 32, 36-60. [CrossRef]

81. Morris, M.H.; Paul, G.W. The relationship between entrepreneurship and marketing in established firms. J. Bus. Ventur. 1987, 2, 247-259. [CrossRef]

82. Naman, J.L.; Slevin, D.P. Entrepreneurship and the concept of fit: A model and empirical tests. Strateg. Manag. J. 1993, 14, 137-153. [CrossRef]

83. Santos-Vijande, M.L.; González-Mieres, C.; Ángel, J. An assessment of innovativeness in KIBS: Implications on KIBS' co-creation culture, innovation capability and performance. J. Bus. Ind. Mark. 2013, 28, 86-102. [CrossRef]

84. García-Rodríguez, N.; Álvarez-Álvarez, B.; Santos-Vijande, M.L. Aplicación de la lógica dominante del servicio (LDS) en el sector turístico: El marketing interno como antecedente de la cultura de co-creación de innovaciones con clientes y empleados. Cuad. Gest. 2010, 11, 53-75. [CrossRef]

85. Wiklund, J. The sustainability of the entrepreneurial orientation-Performance relationship. Entrep. Theory Pract. 1999, 56, 39-48. [CrossRef]

86. Ringle, C.M.; Wende, S.; Becker, J.-M. SmartPLS3; SmartPLS GmbH: Boenningstedt, Germany, 2015. Available online: http://www.smartpls.com (accessed on 20 December 2019).

87. Jarvis, C.; Mackenzie, S.; Podsakoff, P. A critical review of construct indicators and measurement model misspecification in marketing and consumer research. J. Consum. Res. 2003, 30, 199-218. [CrossRef]

88. Real, J.C.; Roldán, J.L.; Leal, A. From entrepreneurial orientation and learning orientation to business performance: Analysing the mediating role of organizational learning and the moderating effects of organizational size. Br. J. Manag. 2014, 25, 186-208. [CrossRef]

89. Bagozzi, R.P. (Ed.) Principles of Marketing Research; Blackwell: Cambridge, MA, USA, 1994; pp. $386-422$.

90. Chin, W.W. How to Write Up and Report PLS Analyses. In Handbook of Partial Least Squares; Springer: Berlin/Heidelberg, Germany, 2010; pp. 655-690. [CrossRef]

91. Lévy-Mangin, J.P.; Varela-Mallou, J. Modelización Con Estructuras De Covarianzas En Ciencias Sociales. Temas Esenciales, Avanzados Y Aportaciones Especiales; Netbiblo: A Coruña, Spain, 2006.

92. Diamantopoulos, A.; Winkholfer, H. Index construction with formative indicators: An alternative to scale development. J. Mark. Res. 2001, 38, 269-277. [CrossRef]

93. Edwards, J.R. Multidimensional Constructs in Organizational Behavior Research: An Integrative Analytical Framework. Organ. Res. Methods 2001, 4, 144-192. [CrossRef]

94. Chin, W.W.; Newsted, P.R. Structural equation modeling analysis with small samples using partial least squares. Stat. Strateg. Small Sample Res. 1999, 1, 307-341.

95. Cohen, J. Statistical Power Analysis for the Behavioral Sciences; Lawrence Earlbam Associates: Hillsdale, NJ, USA, 1988.

96. Wright, R.T.; Campbell, D.E.; Thatcher, J.B.; Nicholas, R. Operationalizing multidimensional constructs in structural equation modeling recommendations. CAIS 2012, 30, 367-412. [CrossRef]

97. Carmines, E.G.; Zeller, R.A. Reliability and Validity Assessment; Sage Publications: Beverly Hills, CA, USA, 1979.

98. Hair, J.F.; Ringle, C.M.; Sarstedt, M. PLS-SEM: Indeed a silver bullet. J. Mark. Theory Pract. 2011, 19, $139-152$. [CrossRef]

99. Fornell, C.; Larcker, D.F. Evaluating structural equation models with unobservable variables and measurement error. J. Mark. Res. 1981, 18, 39-50. [CrossRef]

100. Chin, W.W. The partial least square approach to structural equation modeling. In Modern Methods for Business Research; Lawrence Erlbaum: Mahwah, NJ, USA, 1998; pp. 295-336.

101. Nunnally, J.C. Psychometric Theory; McGrawHill: New York, NY, USA, 1978.

102. Henseler, J.; Chin, W.W. A comparison of approaches for the analysis of interaction effects between latent variables using partial least squares path modeling. Struct. Equ. Modeling 2010, 17, 82-109. [CrossRef]

103. Falk, R.F.; Miller, N.B. A Primer for Soft Modeling; The University of Akron: Akron, OH, USA, 1992. 
104. Wetzels, M.; Odekerken-Schroeder, G.; Van Oppen, C. Using PLS path modelling for assessing hierarchical construct models: Guidelines and empirical illustration. MIS Quart. 2009, 33, 177-195. [CrossRef]

105. Hair, J.F.; Sarstedt, M.; Ringle, C.M.; Gudergan, S.P. Advanced Issues in Partial Least Squares Structural Equations Modeling (PLS-SEM); Sage: Thousand Oaks, CA, USA, 2018.

106. Afonso, C.M.; Roldán, J.L.; Sánchez-Franco, M.; González, M.O. The moderator role of gender in the Unified Theory of Acceptance and Use of Technology (UTAUT): A study on users of Electronic Document Management Systems. In Proceedings of the 7th International Conference on Partial Least Squares and Related Methods, Houston, TX, USA, 19-22 May 2012.

107. Henseler, J.; Fassot, G. Testing moderating effects in PLS path models: An illustration of available procedures (chapter 30). In Handbook of Partial Least Squares; Springer: Berlin/Heidelberg, Germany, 2010; pp. 713-735. [CrossRef]

108. Henseler, J.; Ringle, C.M.; Sarstedt, M. Testing measurement invariance of composites using Partial Least Squares. Int. Mark. Rev. 2016, 33, 405-431. [CrossRef]

109. Qureshi, I.; Compeau, D. Assessing between-group differences in information systems research: A comparison of covariance-and component-based SEM. MIS Q. 2009, 33, 197-214. [CrossRef]

110. Sarstedt, M.; Ringle, C.M.; Henseler, J.; Hair, J.F. On the emancipation of PLS-SEM: A commentary on Rigdon. Long Range Plann. 2014, 47, 154-160. [CrossRef]

111. Henseler, J. Why generalized structured component analysis is not universally preferable to structural equation modeling. J. Acad. Market. Sci. 2012, 40, 402-413. [CrossRef]

112. Schaefer, K.; Corner, P.D.; Kearins, K. Social, environmental and sustainable entrepreneurship research: What is needed for sustainability-as-flourishing? Organ. Environ. 2015, 28, 394-413. [CrossRef]

113. Roxas, B.; Coetzer, A. Institutional environment, managerial attitudes and environmental sustainability orientation of small firms. J. Bus. Ethics 2012, 111, 461-476. [CrossRef]

114. Elkington, J. Cannibals with Forks: The Triple Bottom Line of 21st Century Business; New Society Publishers: Gabriola Island, BC, Canada, 1997.

115. Gao, S.S.; Zhang, J.J. Stakeholder engagement, social auditing and corporate sustainability. Bus. Process Manag. J. 2006, 12, 722-740. [CrossRef]

116. Koe, W.L.; Omar, R.; Majid, I.A. Factors associated with propensity for sustainable entrepreneurship. Procedia-Soc. Behav. Sci. 2014, 130, 65-74. [CrossRef]

117. Sustainable Development Goals. Available online: Sustainabledevelopment.un.org (accessed on 21 January 2020).

(C) 2020 by the authors. Licensee MDPI, Basel, Switzerland. This article is an open access article distributed under the terms and conditions of the Creative Commons Attribution (CC BY) license (http://creativecommons.org/licenses/by/4.0/). 